\title{
In vitro antitumor actions of extracts from endemic plant Helichrysum zivojinii
}

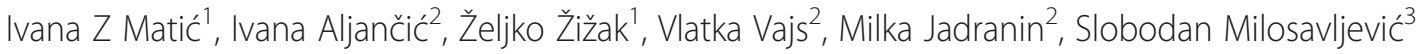
and Zorica D Juranić ${ }^{1^{*}}$

\begin{abstract}
Background: The aim of this research was to determine the intensity and mechanisms of the cytotoxic actions of five extracts isolated from the endemic plant species Helichrysum zivojinii Černjavski \& Soška (family Asteraceae) against specific cancer cell lines. In order to evaluate the sensitivity of normal immunocompetent cells implicated in the antitumor immune response, the cytotoxicity of extracts was also tested against healthy peripheral blood mononuclear cells (PBMC).

Methods: The aerial parts of the plants were air-dried, powdered, and successively extracted with solvents of increasing polarity to obtain hexane, dichloromethane, ethyl-acetate, $n$-butanol and methanol extracts. The cytotoxic activities of the extracts against human cervix adenocarcinoma HeLa, human melanoma Fem-x, human myelogenous leukemia K562, human breast adenocarcinoma MDA-MB-361 cells and PBMC were evaluated by the MTT test. The mode of HeLa cell death was investigated by morphological analysis. Changes in the cell cycle of HeLa cells treated with the extracts were analyzed by flow cytometry. The apoptotic mechanisms induced by the tested extracts were determined using specific caspase inhibitors.
\end{abstract}

Results: The investigated Helichrysum zivojinii extracts exerted selective dose-dependent cytotoxic actions against selected cancer cell lines and healthy immunocompetent PBMC stimulated to proliferate, while the cytotoxic actions exerted on unstimulated PBMC were less pronounced. The tested extracts exhibited considerably stronger cytotoxic activities towards HeLa, Fem-x and K562 cells in comparison to resting and stimulated PBMC. It is worth noting that the cytotoxicity of the extracts was weaker against unstimulated PBMC in comparison to stimulated PBMC. Furthermore, each of the five extracts induced apoptosis in HeLa cells, through the activation of both intrinsic and extrinsic signaling pathways.

Conclusion: Extracts obtained from the endemic plant Helichrysum zivojinii may represent an important source of novel potential antitumor agents due to their pronounced and selective cytotoxic actions towards malignant cells.

Keywords: Helichrysum zivojinii, Cytotoxicity, Cancer cells, Peripheral blood mononuclear cells, Apoptosis

\section{Background}

Bioactive constituents of medicinal plants are in the center of attention of modern anticancer research due to their prospective roles in suppressing the different stages of malignant transformation. The antitumor potential of plant extracts and compounds could be attributed to their ability to induce changes in the regulation of target molecules in oncogenic signal transduction pathways

\footnotetext{
*Correspondence: juranicz@ncrc.ac.rs

'Institute of Oncology and Radiology of Serbia, Pasterova 14, 11000, Belgrade, Serbia

Full list of author information is available at the end of the article
}

implicated in cell growth, replication, apoptosis, as well as in angiogenesis, invasion and metastasis of cancer cells [1-4]. To evaluate the anticancer properties of novel chemotherapeutic agents, the selectivity of their actions against malignant cells in comparison to healthy nontransformed cells, especially immunocompetent cells involved in the immune control of tumor suppression, needs to be carefully examined.

Helichrysum zivojinii Černjavski \& Soška is an endemic plant species that grows in the National Park "Galičica" in Macedonia. Some of the plant species from the large genus Helichrysum are used in different regions 
of the world in traditional medicine for treating wounds, respiratory tract infections and gastro-intestinal disorders [5-8]. This plant genus is a valuable source of several different secondary metabolites/phytochemicals, such as flavonoids, acetophenones, phloroglucinols, pyrones, diterpenes and sesquiterpenes [5]. Different morphological groups of Helichrysum species often display unique qualitative and quantitative chemical compositions [5]. It has been reported that extracts and individual constituents of these plants possess significant biological and pharmacological properties, including antibacterial, antiviral, antifungal, antioxidant, anti-inflammatory and antidiabetic activities [9-16]. A search through the literature suggests that plants from the genus Helichrysum could be a significant source of compounds with potential anticancer activities [17-20].

The main goal of this research was to investigate the cytotoxic activities of five extracts isolated as fractions from the endemic plant Helichrysum zivojinii towards selected human malignant cell lines. To assess the sensitivity of normal immunocompetent cells included in the antitumor immune response, the cytotoxicity of these extracts was also tested against human peripheral blood mononuclear cells (PBMC) - both unstimulated and stimulated to proliferate by the mitogen phytohemagglutinin (PHA). To elucidate the molecular mechanisms of the cytotoxic effects of the tested extracts, the distribution of target HeLa cells at specific phases of the cell cycle after the actions of these agents was also analyzed. The mode of HeLa cell death induced by the extracts was also investigated. Elucidation of the signaling pathways implicated in the induction of apoptosis by the tested extracts was conducted by identification of target caspases.

\section{Methods}

\section{Plant extracts}

The plant material was collected at Tomoros (ca. 1700 altitude), mountain Galičica (Macedonia) during the flowering (17 July 2010) and identified by Vlado Matevski, Institute of Biology, Faculty of Natural Sciences and Mathematics, Ss. Cyril and Methodius University of Skopje, where the voucher specimen is deposited at Macedonian National Herbarium (MKNH) under the number MKNH121335.

Air-dried and powdered aerial parts of Helichrysum zivojinii (330 g) were extracted twice with $n$-hexane in an ultrasonic bath for $45 \mathrm{~min}$. The combined extracts were concentrated in a vacuum to obtain a hexane extract $(4.2 \mathrm{~g})$. The plant material was successively extracted in the same manner with solvents of rising polarity to obtain a dichloromethane extract $(1.4 \mathrm{~g})$, an ethyl-acetate extract $(0.7 \mathrm{~g})$, a $n$-butanol extract $(5.4 \mathrm{~g})$ and finally a methanol extract $(12.4 \mathrm{~g})$.
Stock solutions of the investigated extracts were made in dimethyl sulfoxide (DMSO) at a concentration of $5 \mathrm{mg} / \mathrm{ml}$.

\section{Instrumentation and chromatographic conditions}

${ }^{1}$ HNMR spectra were recorded with Varian Gemini 200 in $\mathrm{CDCl}_{3}$ and DMSO- $\mathrm{d}_{6}$ with TMS as an internal standard. HPLC-MS analysis was performed with an Agilent 1100 Series chromatography system equipped with a binary pump, degasser, autosampler, column Li Chrospher 100 RP $18(250 \times 4,0 \mathrm{~mm}$ i.d. $5 \mu \mathrm{m})$, and DAD detector in combination with 6210 Time of Flight MS (Agilent Technologies). The mobile phase consisted of $0.2 \%$ formic acid in water (solvent A) and 100\% acetonitrile (solvent B) with the following gradient elution: $0-5 \mathrm{~min} 10-20 \%$ B, 5-10 min $20 \% \mathrm{~B}, 10-20 \mathrm{~min} 20-30 \% \mathrm{~B}, 20-30 \mathrm{~min}$ $30-70 \% \mathrm{~B}, 30-35 \mathrm{~min} 70-100 \% \mathrm{~B}, 35-40 \mathrm{~min} 70 \% \mathrm{~B}$, $40-41 \mathrm{~min} 100-10 \% \mathrm{~B}, 41-45 \mathrm{~min} 10 \% \mathrm{~B}$, at a flow rate of $1 \mathrm{ml} / \mathrm{min}$. The injection volume was $10 \mu \mathrm{L}$, the column temperature was $25^{\circ} \mathrm{C}$. The effluent was monitored with DAD (190-550 nm) and a mass detector (ESI) which operated in negative mode at atmospheric pressure; the mass range was from $m / z$ 100-2500, with the following ESI parameters: capillary voltage: $4000 \mathrm{~V}$; gas temperature: $350^{\circ} \mathrm{C}$; nebulizer pressure: 45 psig; fragmentor voltage: $140 \mathrm{~V}$. Mass Hunter Workstation software was used for data analysis.

\section{Cell culture}

Human cervix adenocarcinoma HeLa, human melanoma Fem-x and human breast adenocarcinoma MDAMB-361 cells were cultured as monolayers. Human chronic myelogenous leukemia K562 cells were grown in a suspension in nutrient medium. Cancer cell lines were obtained from the American Type Culture Collection (Manassas, VA, USA). The complete nutrient medium was RPMI 1640 supplemented with $3 \mathrm{mM}$ L-glutamine, $100 \mu \mathrm{g} / \mathrm{ml}$ streptomycin, $100 \mathrm{IU} / \mathrm{ml}$ penicillin, $10 \%$ heatinactivated $\left(56^{\circ} \mathrm{C}\right)$ fetal bovine serum and $25 \mathrm{mM}$ Hepes adjusted to $\mathrm{pH} 7.2$ with a bicarbonate solution. The cells were grown at $37^{\circ} \mathrm{C}$ in an atmosphere of $5 \% \mathrm{CO}_{2}$ and humidified air. RPMI 1640, L-glutamine and Hepes were obtained from PAA (Pasching, Austria).

\section{Preparation of peripheral blood mononuclear cells}

Peripheral blood mononuclear cells (PBMC) were separated from whole heparinized blood of two healthy volunteers by Lymphoprep (Oslo, Norway) gradient centrifugation. Interface cells were washed three times with Haemaccel (aqueous solution supplemented with $145 \mathrm{mM}$ $\mathrm{Na}^{+}, 5.1 \mathrm{mM} \mathrm{K}+, 6.2 \mathrm{mM} \mathrm{Ca}{ }^{+}, 145 \mathrm{mM} \mathrm{Cl}^{-}$and $35 \mathrm{~g} / \mathrm{l}$ gelatin polymers, $\mathrm{pH} 7.4$ ), counted and resuspended in nutrient medium. The protocol of the study was approved by the Ethics Committee of the Institute of Oncology and 
Radiology of Serbia. Written informed consent was obtained from each healthy donor.

\section{Treatment of cancer cell lines}

HeLa (2,000 cells per well), Fem-x (2,000 cells per well), MDA-MB-361 (10,000 cells per well) were seeded into 96-well microtiter plates and $20 \mathrm{~h}$ later, after cell adherence, five different concentrations of the tested extracts were added to the wells. Nutrient medium was only added to the cells in the control wells. K562 cells (5,000 cells per well) were seeded $2 \mathrm{~h}$ before addition of the extracts. Stock solutions of plant extracts were diluted with complete nutrient medium and applied to target cells at different final concentrations that ranged from $6.25 \mu \mathrm{g} / \mathrm{ml}$ to $100 \mu \mathrm{g} / \mathrm{ml}$ for extracts $1-4$, and from $12.5 \mu \mathrm{g} / \mathrm{ml}$ to $150 \mu \mathrm{g} / \mathrm{ml}$ or $200 \mu \mathrm{g} / \mathrm{ml}$ for extract 5 . All experiments were done in triplicate. Cisplatin was used as a positive control.

\section{Treatment of PBMC}

PBMC (150,000 cells per well) were seeded into nutrient medium or in nutrient medium enriched with $(5 \mu \mathrm{g} / \mathrm{ml})$ (PHA) in 96-well microtiter plates. After $2 \mathrm{~h}$, five different concentrations of the plant extracts were added to the individual wells, in triplicate, except to the control wells where a nutrient medium only was added to the cells. The final concentrations of the tested extracts ranged from $12.5 \mu \mathrm{g} / \mathrm{ml}$ to $200 \mu \mathrm{g} / \mathrm{ml}$. PHA was obtained from INEP (Belgrade, Serbia). Cisplatin was used as a positive control.

\section{Determination of target cell survival}

Cell survival was determined by the MTT test according to the method of Mosmann [21] and modified by Ohno and Abe [22]. Briefly, after the treatment with plant extracts for $72 \mathrm{~h}, 10 \mu \mathrm{l}$ of MTT solution (3-(4,5-dimethylthiazol-2-yl)2,5-dyphenyl tetrazolium bromide) was added to each well. Samples were incubated for a further $4 \mathrm{~h}$, followed by the addition of $100 \mu \mathrm{l}$ of $10 \%$ SDS. Absorbance at $570 \mathrm{~nm}$ was measured the next day.

To quantify cell survival (S\%), the absorbance of a sample with cells grown in the presence of different concentrations of the investigated agents was divided by the absorbance of the control cells grown only in the nutrient medium, and multiplied by 100. It is implied that the absorbance of the blank was always subtracted from the absorbance of the corresponding sample with target cells. The $\mathrm{IC}_{50}$ was defined as the concentration of the agent that inhibited cell survival by $50 \%$, compared to the vehicle-treated control.

\section{Morphological evaluation of HeLa cell death}

To evaluate whether the extracts from the endemic plant Helichrysum zivojinii induce apoptosis in HeLa cells, morphological analysis by microscopic examination of acridine orange/ethidium bromide-stained target cells was performed. HeLa cells were seeded overnight on coverslips $(100,000$ cells) in $2 \mathrm{ml}$ of complete medium. The next day, cells were treated with plant extracts for $24 \mathrm{~h}$ at concentrations corresponding to $\mathrm{IC}_{90}$ values that were obtained after treatments that lasted $72 \mathrm{~h}$. After this period, the target cells were stained with $18 \mu \mathrm{l}$ of a mixture of the DNA dyes acridine orange and ethidium bromide $(3 \mu \mathrm{g} / \mathrm{ml} \mathrm{AO}$ and $10 \mu \mathrm{g} / \mathrm{ml} \mathrm{EB}$ in PBS), and visualized under a fluorescence microscope using a fluorescein isothiocyanate (FITC) filter set.

\section{Cell cycle analysis}

HeLa cells were incubated in the presence of two different concentrations (corresponding to the $\mathrm{IC}_{50}$ and $\mathrm{IC}_{90}$ values determined after $72 \mathrm{~h}$ ) of the examined Helichrysum zivojinii extracts for 24, 48 and $72 \mathrm{~h}$. After these incubation times, the target cells were collected, washed and

Table 1 Components of five Helichrysum zivojinii extracts

\begin{tabular}{|c|c|c|c|c|c|c|}
\hline \multirow{2}{*}{\multicolumn{2}{|c|}{ Compounds }} & \multicolumn{5}{|c|}{ Extracts } \\
\hline & & \multirow{2}{*}{$\begin{array}{c}\text { Hexane } \\
(1) \\
-\end{array}$} & \multirow{2}{*}{$\begin{array}{c}\mathrm{CH}_{2} \mathrm{Cl}_{2} \\
(2) \\
+\end{array}$} & \multirow{2}{*}{$\begin{array}{c}\text { EtOAc } \\
(3) \\
+\end{array}$} & \multirow{2}{*}{$\begin{array}{c}\mathrm{BuOH} \\
(4) \\
+\end{array}$} & \multirow{2}{*}{$\begin{array}{c}\mathrm{MeOH} \\
(5) \\
+\end{array}$} \\
\hline 1. & $\begin{array}{l}\mathrm{C}_{8} \mathrm{H}_{6} \mathrm{O}_{4}(166) \\
\text { Phtalic acid }\end{array}$ & & & & & \\
\hline 2. & $\begin{array}{l}\mathrm{C}_{21} \mathrm{H}_{20} \mathrm{O}_{12} \text { (464) } \\
\text { O-glc or } \mathrm{O} \text {-gal of } \\
\text { quercetin }\end{array}$ & - & - & + & + & + \\
\hline 3. & $\begin{array}{l}\mathrm{C}_{25} \mathrm{H}_{24} \mathrm{O}_{12}(516) \\
\text { chlorogenic acids }\end{array}$ & - & - & + & + & $++^{a}$ \\
\hline 4. & $\begin{array}{l}\mathrm{C}_{21} \mathrm{H}_{20} \mathrm{O}_{11}(448) \\
\mathrm{O}-\text { glc of apigenin }\end{array}$ & - & - & + & $++^{a}$ & + \\
\hline 5. & $\begin{array}{l}\mathrm{C}_{21} \mathrm{H}_{20} \mathrm{O}_{10}(432) \\
\text { O-glc of kaempferol } \\
\text { or luteolin }\end{array}$ & - & - & + & + & + \\
\hline 6. & $\begin{array}{l}\mathrm{C}_{21} \mathrm{H}_{20} \mathrm{O}_{11}(448) \\
\mathrm{O}-\mathrm{glc} \text { of apigenin }\end{array}$ & - & - & + & + & + \\
\hline 7. & $\begin{array}{l}\mathrm{C}_{19} \mathrm{H}_{30} \mathrm{O}_{14} \text { or } \\
\mathrm{C}_{26} \mathrm{H}_{26} \mathrm{O}_{9}(482)\end{array}$ & + & + & - & - & - \\
\hline 8. & $\begin{array}{l}\mathrm{C}_{15} \mathrm{H}_{10} \mathrm{O}_{6}(286) \\
\mathrm{O} \text {-glc of flavonols } \\
\text { kaempferol, } \\
\text { luteolin or } \\
\text { 6-hydroxyapigenin }\end{array}$ & - & - & + & + & + \\
\hline 9. & $\begin{array}{l}\mathrm{C}_{21} \mathrm{H}_{24} \mathrm{O}_{9} \text { or } \\
\mathrm{C}_{14} \mathrm{H}_{28} \mathrm{O}_{14} \text { (420) }\end{array}$ & + & + & - & - & - \\
\hline 10. & $\begin{array}{l}\mathrm{C}_{15} \mathrm{H}_{12} \mathrm{O}_{5}(272) \\
\text { flavanone } \\
\text { naringenin }\end{array}$ & - & + & + & + & + \\
\hline 11. & $\begin{array}{l}\mathrm{C}_{22} \mathrm{H}_{26} \mathrm{O}_{9} \text { or } \\
\mathrm{C}_{15} \mathrm{H}_{30} \mathrm{O}_{14} \text { (434) }\end{array}$ & + & + & - & - & - \\
\hline 12. & $\begin{array}{l}\mathrm{C}_{15} \mathrm{H}_{10} \mathrm{O}_{5}(270) \\
\text { apigenin }\end{array}$ & - & + & $++^{a}$ & + & + \\
\hline 13. & $\mathrm{C}_{21} \mathrm{H}_{18} \mathrm{O}_{4}$ (334) & + & - & - & - & - \\
\hline 14. & $\mathrm{C}_{18} \mathrm{H}_{16} \mathrm{O}_{7}$ (344) & + & - & - & - & - \\
\hline
\end{tabular}

${ }^{\mathrm{a}}$ More abundant on the expense of other fraction constituents. 

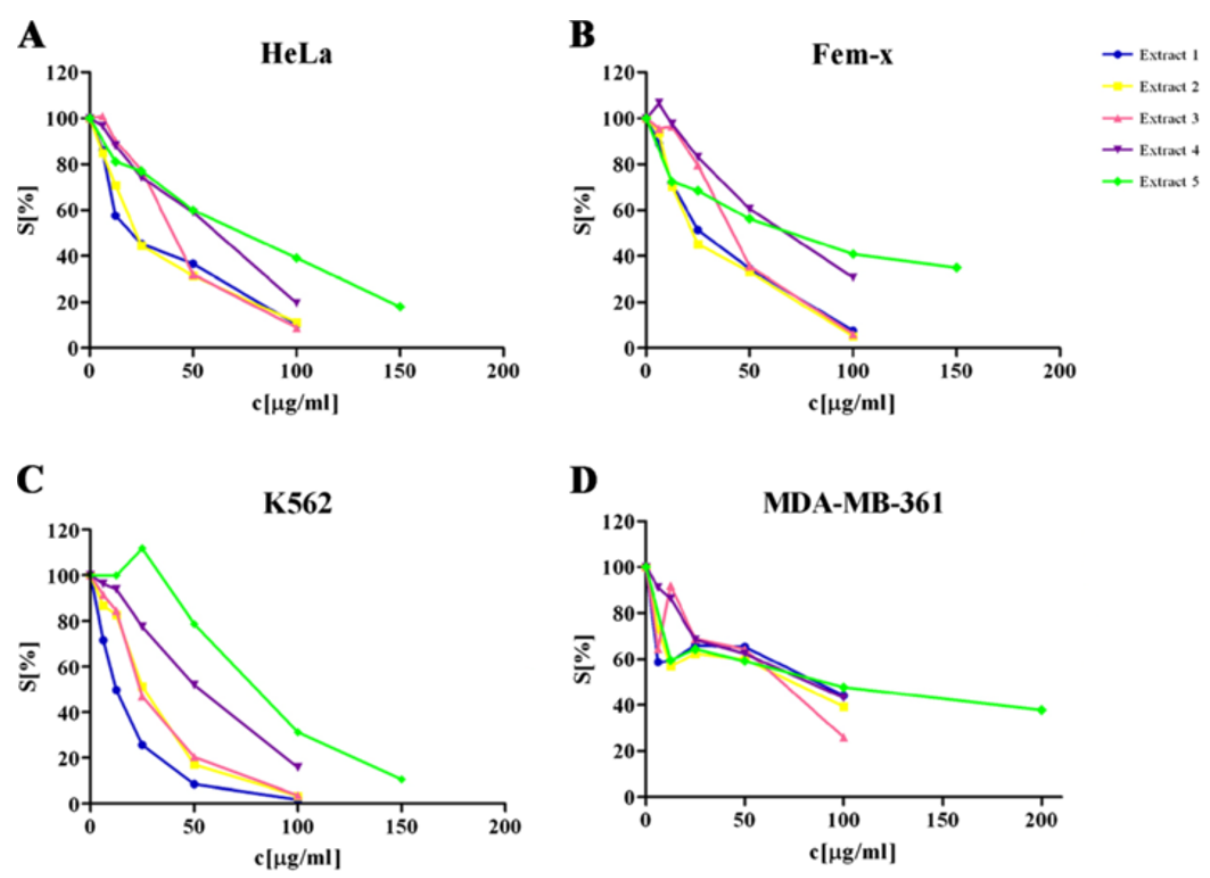

Figure 1 Survival of HeLa (A), Fem-x (B), K562 (C) and MDA-MB-361 cells (D) grown for $72 \mathrm{~h}$ in the presence of increasing concentrations of Helichrysum zivojinii extracts, determined by MTT test. Representative graphs are shown.

fixed in $70 \%$ ethanol on ice. Samples were stored at $-20^{\circ} \mathrm{C}$ for one week before staining. HeLa cells were washed in PBS, resuspended in $500 \mu$ l of staining solution (PBS containing RNAse A at a final concentration of $200 \mu \mathrm{g} /$ $\mathrm{ml}$, and propidium iodide (PI) at a final concentration of $20 \mu \mathrm{g} / \mathrm{ml})$, and incubated for $30 \mathrm{~min}$ at $37^{\circ} \mathrm{C}$.

Cell cycle phase distribution was determined using a FACSCalibur Flow Cytometer (BD Biosciences Franklin Lakes, NJ, USA). The data (10,000 events collected for each sample) were analyzed using CELLQuest software (BD Biosciences).

\section{Determination of target caspases}

To identify the caspases involved in the apoptotic cell death pathway induced by the investigated extracts, the percentages of HeLa cells pretreated with caspase inhibitors in the subG1 phase were determined. HeLa cells were preincubated for $2 \mathrm{~h}$ with specific caspase inhibitors (at a final concentration of $40 \mu \mathrm{M}$ ). These were: Z-DEVD-FMK, a caspase-3 inhibitor, Z-IETD-FMK, a caspase-8 inhibitor and Z-LEHD-FMK, a caspase-9 inhibitor. Caspase inhibitors were purchased from R\&D Systems (Minneapolis, USA). Five tested extracts were applied to the HeLa cells at concentrations that corresponded to the $\mathrm{IC}_{90}$ values obtained after $72 \mathrm{~h}$. For each extract, one sample of HeLa cells was not treated with an inhibitor and served as a reference sample. After $24 \mathrm{~h}$ of incubation, cells were harvested and fixed in $70 \%$ ethanol on ice. Samples were stored at $-20^{\circ} \mathrm{C}$ for one week before PI staining. Changes in the percentages of cells in the subG1 phase were determined using a FACSCalibur Flow Cytometer and analyzed using CELLQuest software.

Table 2 Concentrations of five Helichrysum zivojinii extracts, which induced $50 \%$ decrease in the target cancer cell survival, determined by MTT test

\begin{tabular}{|c|c|c|c|c|}
\hline & HeLa & Fem-x & K562 & MDA-MB-361 \\
\hline Extract $1 \mathrm{IC} C_{50}[\mu \mathrm{g} / \mathrm{ml}]$ & $24.63 \pm 4.12$ & $28.85 \pm 5.49$ & $11.78 \pm 0.94$ & $81.74 \pm 6.27$ \\
\hline Extract $2 \mathrm{IC}_{50}[\mu \mathrm{g} / \mathrm{ml}]$ & $20.11 \pm 4.49$ & $23.64 \pm 1.41$ & $23.82 \pm 6.54$ & $81.74 \pm 13.31$ \\
\hline Extract $3 I_{50}[\mu \mathrm{g} / \mathrm{ml}]$ & $37.98 \pm 2.33$ & $47.04 \pm 4.79$ & $27.52 \pm 4.96$ & $79.93 \pm 13.49$ \\
\hline Extract $4 \mathrm{IC}_{50}[\mu \mathrm{g} / \mathrm{ml}]$ & $56.70 \pm 6.05$ & $74.84 \pm 7.55$ & $50.37 \pm 3.28$ & $69.96 \pm 11.70$ \\
\hline Extract $5 \mathrm{IC}_{50}[\mu \mathrm{g} / \mathrm{ml}]$ & $84.68 \pm 10.39$ & $77.29 \pm 6.55$ & $74.88 \pm 7.57$ & $94.92 \pm 6.85$ \\
\hline Cisplatin $\mathrm{IC}_{50}[\mu \mathrm{M}]$ & $5.60 \pm 1.41$ & $5.02 \pm 0.59$ & $5.35 \pm 0.70$ & $28.23 \pm 5.04$ \\
\hline
\end{tabular}

Time of continuous agent's action was $72 \mathrm{~h}$. 

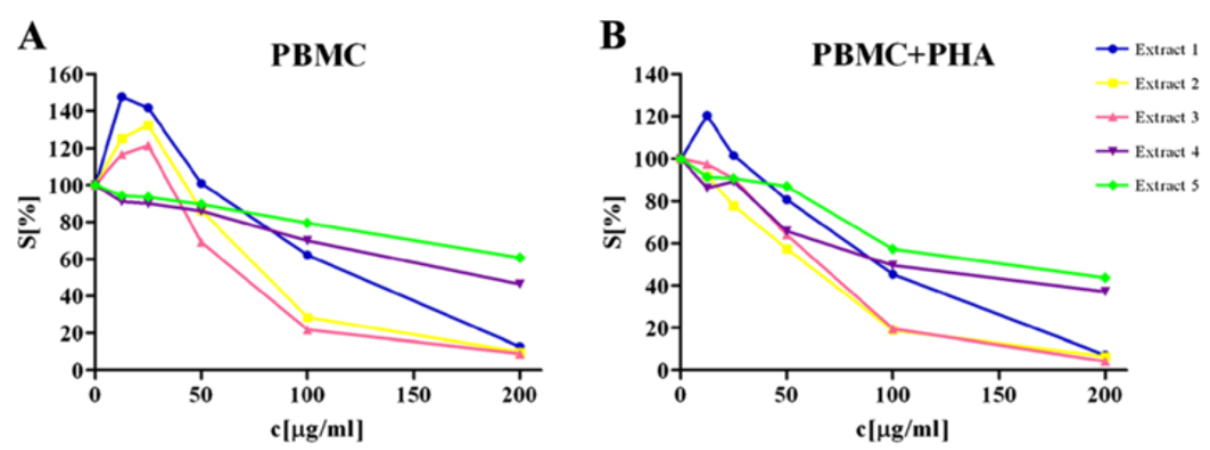

Figure 2 Survival of resting PBMC (A) and PHA-stimulated PBMC (B) grown for $72 \mathrm{~h}$ in the presence of increasing concentrations of Helichrysum zivojinii extracts, determined by MTT test. Representative graphs are shown.

\section{Results}

\section{Chemical analysis of plant extracts}

The hexane (1) and dichloromethane extracts (2) presented similar ${ }^{1} \mathrm{H}$ NMR spectra (recorded in $\mathrm{CDCl}_{3}$ ). The signals in the ${ }^{1} \mathrm{H}$ NMR spectra of both extracts pointed to a complex mixture with prevailing relatively non-polar substances (region $\delta 0.8-2.2$ ). LC/DAD analysis revealed the presence of a flavonoid with the molecular formula $\mathrm{C}_{18} \mathrm{H}_{16} \mathrm{O}_{7}$ (344) in the hexane extract, while the flavanone naringenin and flavone apigenin were confirmed in the dichloromethane extract, also by LC/DAD analysis. Three compounds found in both extracts are presented in Table 1, with their presumed molecular formulae and measured $\mathrm{m} / \mathrm{z}$ values corresponding to identified ions obtained by ESI ToF mass spectrometry. According to LC/DAD analysis, these compounds unfortunately did not absorb in the UV spectrum, suggesting the presence of structures without a chromophore. The ethylacetate extract (3) and $n$-butanol extracts (4) presented ${ }^{1} \mathrm{H}$ NMR spectra (recorded in DMSO- $\mathrm{d}_{6}$ ) with approximately identical groups of signals in the regions $\delta 12.5-$ 13.9 (hydroxy protons), $\delta$ 5.9-8.1 (protons on the aromatic ring that is substituted with one or more hydroxy groups), and $\delta$ 4.7-5.5 (group of protons corresponding to a sugar unit). The ${ }^{1} \mathrm{H}$ NMR spectrum of the most abundant methanol extract (5), also recorded in DMSO- $\mathrm{d}_{6}$, resembles the spectra of the ethyl-acetate and $n$-butanol extracts by the presence of signals in the region $\delta$ 5.9-8.1 (aromatic protons), as well as by the presence of a signal at $\delta 13.9$ (hydroxy proton); it differs from the last two spectra by possessing a more pronounced region at $\delta 4.7-5.5$, which is responsible for the protons of sugar units. LC/DAD analysis and ESI ToF mass spectrometry of these three more polar extracts (3, 4 and 5) revealed quite similar constituents in each of them. Apart from chlorogenic acid, two groups of flavonoid compounds were detected: flavonoid $\mathrm{O}$-glycosides, and flavonoid aglycons. Among the $\mathrm{O}$ glycosides, the glucoside (or possibly galactoside) of quercetin, the glucoside of apigenin, the glucoside of kaempferol (or possibly luteolin), and another glucoside of kaempferol (possibly luteolin or 6-hydroxyapigenin), were present. Flavonoid aglycones, such as apigenin and naringenin, were detected. Phthalic acid was found in extracts $2-5$.

\section{In vitro cytotoxic activity}

The cytotoxicity of the five isolated extracts was tested against selected cancer cell lines: human cervix adenocarcinoma HeLa, human melanoma Fem-x, human myelogenous leukemia K562 and human breast adenocarcinoma MDA-MB-361 cells. All investigated extracts exerted selective dose-dependent cytotoxic actions on malignant cells. The decrease in survival of target cancer cells induced by the five Helichrysum zivojinii extracts is shown in Figure 1 and Table 2.

In general, extracts 1 and 2 (as well as cisplatin, which served as a positive control) exhibited the highest cytotoxic actions against target malignant cell lines; extracts 3 and 4 displayed less pronounced cytotoxicity; extract 5 had the lowest cytotoxic action.

With regard to the specific sensitivities of the different cells to the cytotoxic activities of the extracts, it is important to note that K562 cells were the most sensitive to the cytotoxic actions of extracts 1 and 3. HeLa and Fem-x cells exhibited a lower sensitivity, while the sensitivity of breast cancer MDA-MB-361 cells to the toxic

Table 3 Concentrations of five Helichrysum zivojinii extracts, which induced 50\% decrease in target PBMC survival, determined by MTT test

\begin{tabular}{|c|c|c|}
\hline & PBMC & $\mathrm{PBMC}+\mathrm{PHA}$ \\
\hline Extract $1 \mathrm{IC}_{50}[\mu \mathrm{g} / \mathrm{ml}]$ & $131.59 \pm 9.93$ & $99.07 \pm 8.02$ \\
\hline Extract $2 \mathrm{IC}_{50}[\mu \mathrm{g} / \mathrm{ml}]$ & $81.74 \pm 0.50$ & $67.65 \pm 11.37$ \\
\hline Extract $3 \mathrm{IC}_{50}[\mu \mathrm{g} / \mathrm{ml}]$ & $74.82 \pm 6.51$ & $61.86 \pm 5.53$ \\
\hline Extract $4 \mathrm{IC}_{50}[\mu \mathrm{g} / \mathrm{ml}]$ & 185.17 & $92.20 \pm 9.01$ \\
\hline Extract $5 \mathrm{IC}_{50}[\mu \mathrm{g} / \mathrm{ml}]$ & $>200$ & $128.12 \pm 35.46$ \\
\hline Cisplatin $\mathrm{IC}_{50}[\mu \mathrm{M}]$ & $>33.34$ & $>33.34$ \\
\hline
\end{tabular}

Time of continuous agent's action was $72 \mathrm{~h}$. 
Table 4 Selectivity in the antitumor action of five Helichrysum zivojinii extracts

\begin{tabular}{|c|c|c|c|c|}
\hline $\begin{array}{l}\text { Selectivity } \\
\text { coefficient in the } \\
\text { antitumor action }\end{array}$ & $\begin{array}{l}\mathrm{IC}_{50} \mathrm{PBMC} / \\
\mathrm{IC}_{50} \mathrm{HeLa}\end{array}$ & $\begin{array}{c}\mathrm{IC}_{50} \mathrm{PBMC} \\
+\mathrm{PHA} / \\
\mathrm{IC}_{50} \mathrm{HeLa} \\
\end{array}$ & $\begin{array}{l}\mathrm{IC}_{50} \mathrm{PBMC} / \\
\mathrm{IC}_{50} \mathrm{~K} 562\end{array}$ & $\begin{array}{c}\mathrm{IC}_{50} \mathrm{PBMC} \\
+\mathrm{PHA} / \\
\mathrm{IC}_{50} \mathrm{~K} 562 \\
\end{array}$ \\
\hline Extract 1 & 5.34 & 4.02 & 11.17 & 8.41 \\
\hline Extract 2 & 4.06 & 3.36 & 3.43 & 2.84 \\
\hline Extract 3 & 1.97 & 1.63 & 2.78 & 2.25 \\
\hline Extract 4 & 3.27 & 1.63 & 3.68 & 1.83 \\
\hline Extract 5 & $>2.36$ & 1.51 & 2.67 & 1.71 \\
\hline
\end{tabular}

C

E
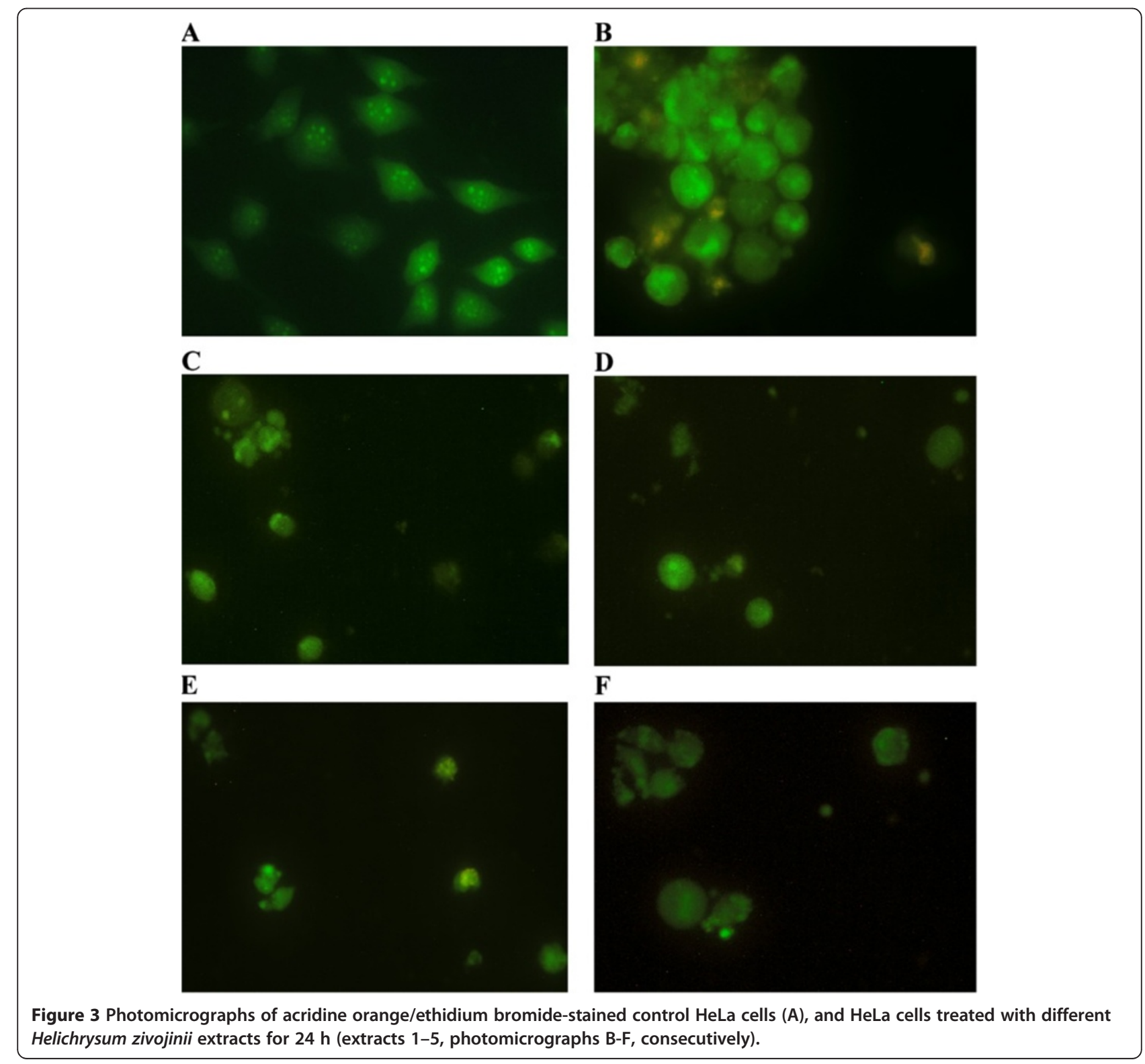

actions of the tested extracts was the lowest (being several times lower than that of the other cell lines to extracts 1, 2 and 3 especially).

Considering the possible effects of applied antitumor drugs on normal healthy immunocompetent cells, components of the antitumor immune response, their viability is significant for tumor control. For that reason, the activities of the investigated Helichrysum zivojinii extracts were evaluated against healthy unstimulated and PHA-stimulated PBMC (Figure 2 and Table 3). It should be noted that these extracts overall exhibited weaker cytotoxic effects against unstimulated PBMC than against stimulated PBMC. Moreover, extracts 2 and 3 exerted a more pronounced cytotoxicity against unstimulated and PHA-stimulated PBMC than extracts 1,4 and 5. 

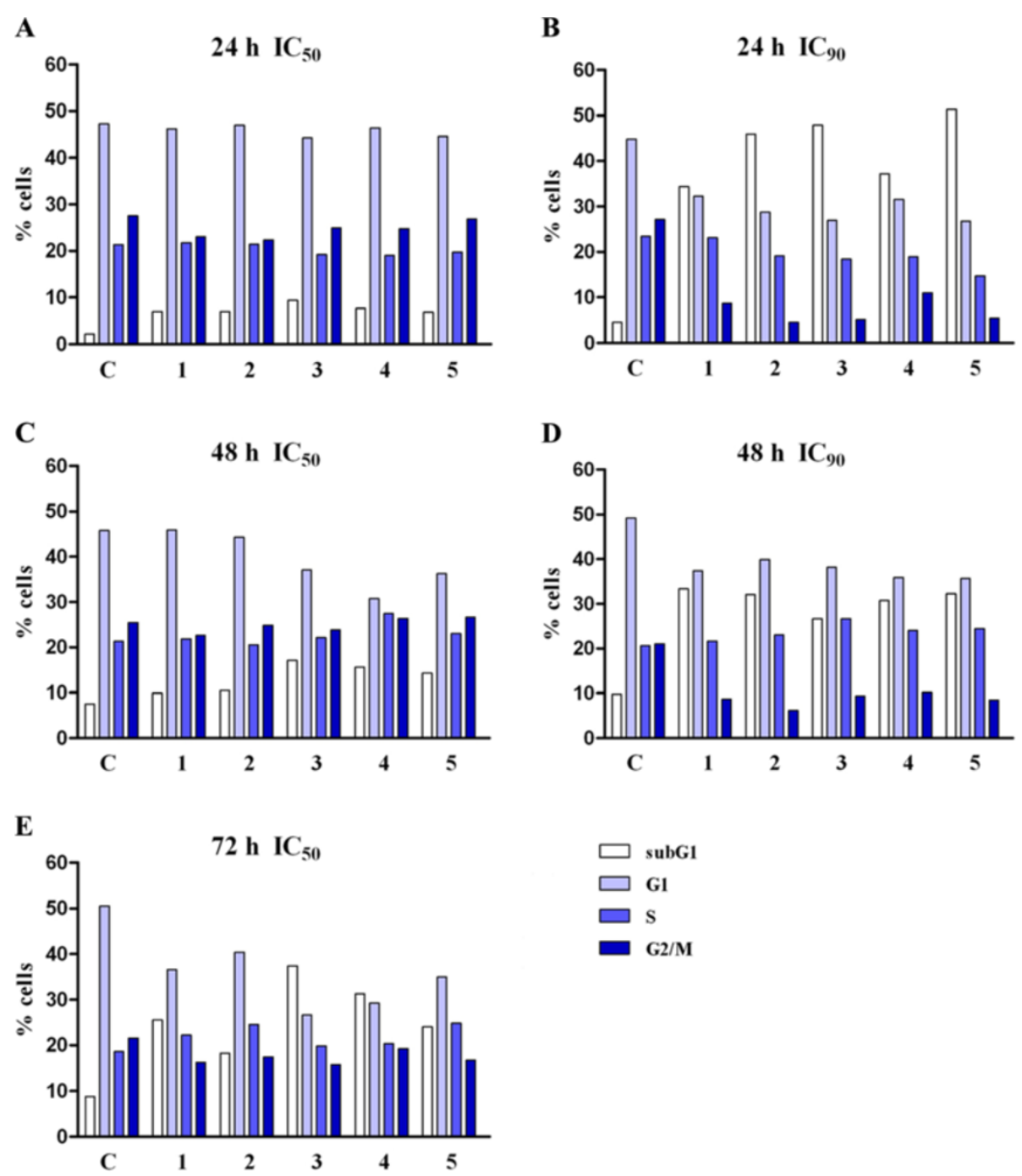

Figure 4 Changes in the cell cycle phase distribution of HeLa cells induced by the Helichrysum zivojinii extracts after $24(A, B), 48(C, D)$ and $72 \mathrm{~h}(\mathrm{E})$ treatment (applied concentrations of tested extracts corresponded to $I C_{50}$ and IC 90 values determined for $72 \mathrm{~h}$ ). (C- COntrol HeLa cells, 1 - 5 - corresponding extracts are numbered consecutively). Representative graphs are shown.

In order to further evaluate the anticancer potential of the extracts, the selectivity in the antitumor action against specific malignant cell line in comparison to healthy PBMC was determined as well. These data are presented in Table 4 from which it can be observed that extract 1 exhibited highly selective antitumor action, especially against K562 cells. Extract 2 also displayed good selectivity in its antitumor action.

\section{Morphological analysis of HeLa cell death mode}

In order to determine whether the investigated plant extracts have pro-apoptotic activities, we performed morphological analysis by fluorescent microscopy of acridine orange/ethidium bromide-stained HeLa cells, exposed to the extracts. Microscopic examination revealed that all five extracts applied at $\mathrm{IC}_{90}$ concentrations induced apoptosis in target HeLa cells after $24 \mathrm{~h}$ treatment (Figure 3). The morphological characteristics of apoptotic cell death, such as cell shrinkage, condensation and even fragmentation of nucleus, as well as the presence of orange-red stained cells at late stages of apoptosis or secondary necrosis (the latter was observed in extract 1treated HeLa cells) and apoptotic bodies. These analyses confirmed that the cytotoxicity of the Helichrysum zivojinii extracts is based on their prominent proapoptotic effects.

\section{Analysis of changes in cell cycle phase distribution}

Examination of changes in the cell cycle phase distribution of HeLa cells treated with these extracts for 24, 48 and $72 \mathrm{~h}$ was done to elucidate the mechanisms of the observed cytotoxic actions (Figure 4). Results from this 

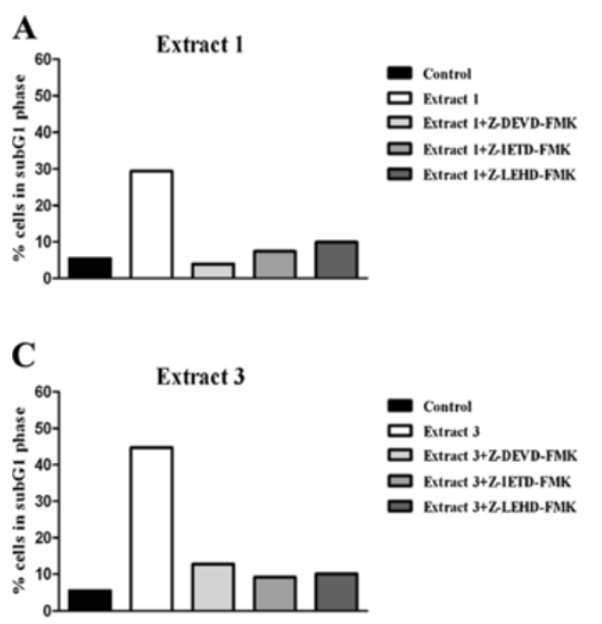

$\mathbf{E}$

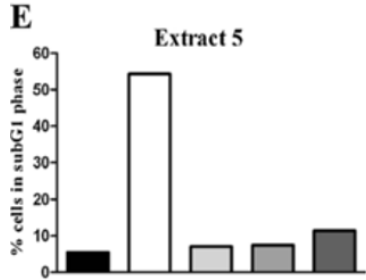

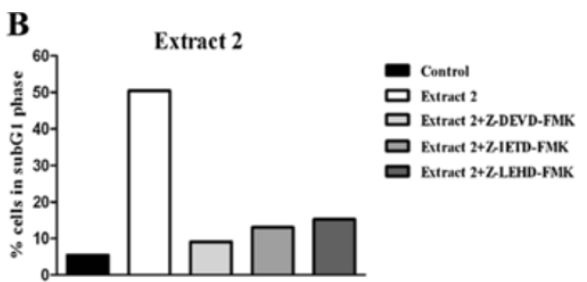

D

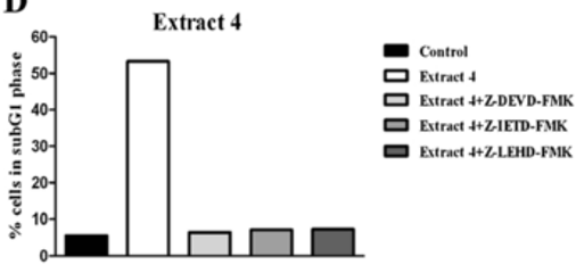

Figure 5 Effects of specific caspase inhibitors on the percentages of apoptotic subG1 HeLa cells treated with Helichrysum zivojinii extracts for 24 h (A - extract 1, B - extract 2, C - extract 3, D - extract 4, E - extract 5). (Z-DEVD-FMK - caspase-3 inhibitor; Z-IETD-FMK caspase-8 inhibitor; Z-LEHD-FMK - caspase-9 inhibitor).

analysis showed a time - dependent increase in the percentages of HeLa cells in the subG1 phase after exposure to an $\mathrm{IC}_{50}$ concentration of all of the tested extracts. Additionally, exposure to extracts at $\mathrm{IC}_{90}$ concentrations induced significant increases in the percentages of cells in the subG1 phase $24 \mathrm{~h}$ after exposure. It should be mentioned that the investigated extracts induced a slight accumulation of HeLa cells in the S phase after $72 \mathrm{~h}$. Examination of the cell cycle changes that were induced after exposure for $72 \mathrm{~h}$ to $\mathrm{IC}_{90}$ for each extract was not performed because at this time point and at this extract concentration low numbers of mostly dead or dying cells were present in the sample.

Since the Helichrysum zivojinii extracts exhibited the pro-apoptotic activities against cervix adenocarcinoma HeLa cells, the identification of target caspases involved in the apoptotic pathway was performed. The presence of the specific caspase inhibitors (caspase- 3 inhibitor, caspase- 8 inhibitor or caspase-9 inhibitor) significantly reduced the percentages of apoptotic subG1 HeLa cells treated with each of the five plant extracts, as shown in Figure 5. The effect of the caspase-3 inhibitor on HeLa cells treated with extracts is shown in Figure 6. It can be seen that there is an increase in rounded, but attached and live HeLa cells treated with the caspase- 3 inhibitor before the addition of the extracts in relation to target HeLa cells only exposed to the tested extracts.

\section{Discussion}

The plant kingdom provides a rich source of compounds with promising cancer chemopreventive and cancer therapeutic potential. The main drugs currently used in clinical practice in the treatment of malignant diseases originate from plants: vinca alkaloids, taxanes, camptothecins and epipodophyllotoxins [23]. Over the past years, the focus of modern anticancer drug discovery has been on a wide variety of natural compounds, especially on phenolic compounds. Phytochemicals have been reported to affect different intracellular signaling pathways implicated in the initiation, promotion and progression of cancer. The antitumor effects of plant constituents have been associated with the induction of carcinogen detoxifying enzymes, the scavenging of free radicals, anti-inflammatory activity, cell cycle arrest, the triggering of apoptosis, inhibition of tumor angiogenesis and invasiveness [1-4].

The antioxidant and anti-inflammatory activities of extracts and isolated compounds from plants belonging to the large genus Helichrysum have been well documented $[9,11,15,18]$. Arzanol, a phloroglucinyl $\alpha$-pyrone, is a constituent of Helichrysum italicum that has been reported to inhibit the NF- $\mathrm{kB}$ transcription factor, cyclooxygenase and lipooxygenase, as well as the release of proinflammatory cytokines $[11,18]$. Regarding the link between inflammation and cancer, chemicals with anti-inflammatory properties targeting the molecules of signaling cascades 


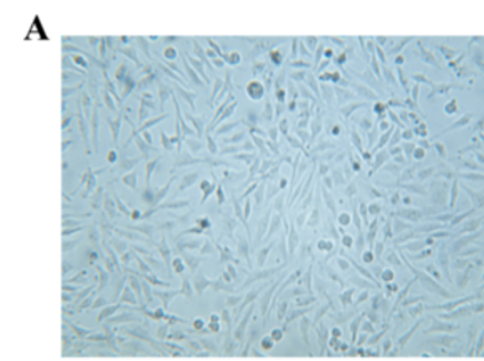

B

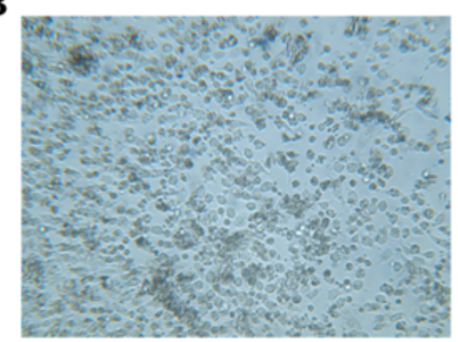

D

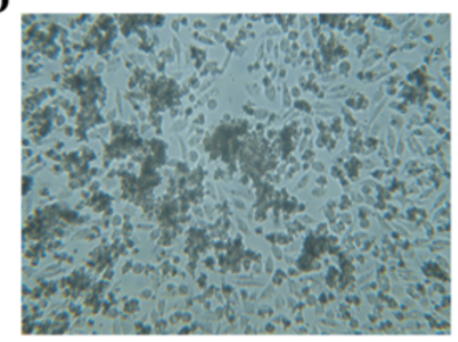

F

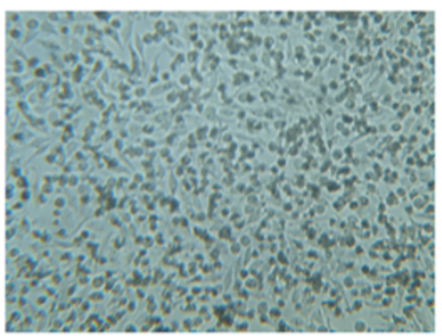

$\mathbf{H}$

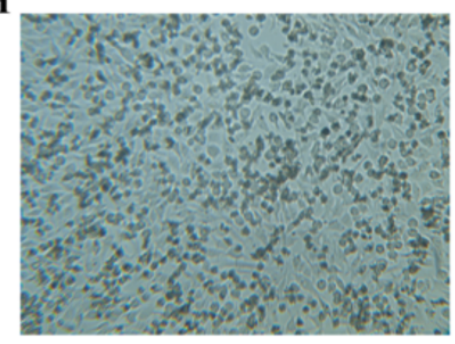

$\mathbf{J}$

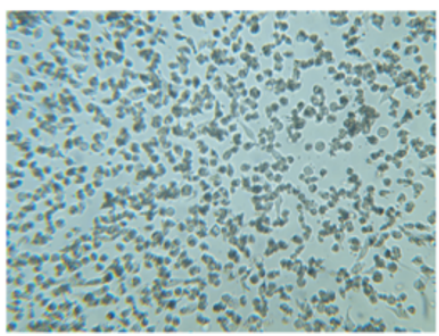

C

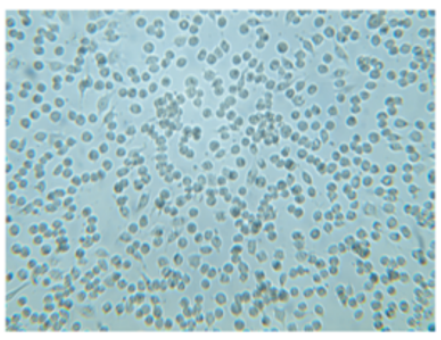

E

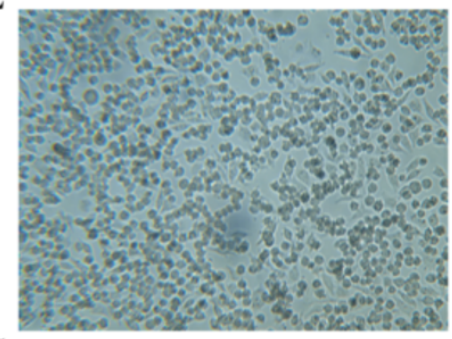

G

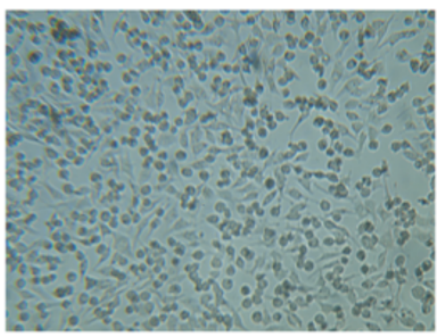

I

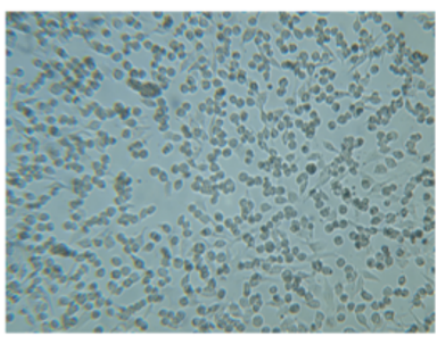

$\mathbf{K}$

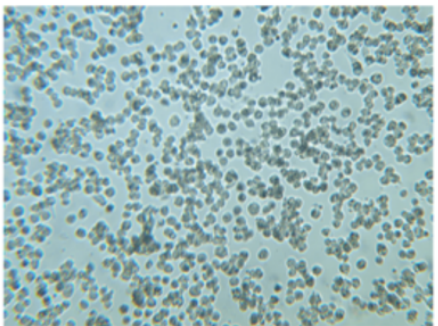

Figure 6 (See legend on next page.) 
(See figure on previous page.)

Figure 6 Effects of pretreatment of HeLa cells with caspase-3 inhibitor (Z-DEVD-FMK), exposed to Helichrysum zivojinii extracts (applied concentrations of tested extracts corresponded to $\mathbf{I C}_{\mathbf{9 0}}$ values determined for $\mathbf{7 2} \mathbf{h}$ ). $\mathbf{A}$ - control; $\mathbf{B}-$ Extract $1, \mathbf{C}-$ Extract $1+Z$ DEVD-FMK; D - Extract 2, E - Extract 2 + Z-DEVD-FMK; $\mathbf{F}$ - Extract 3, G - Extract 3 + Z-DEVD-FMK; $\mathbf{H}$ - Extract 4, I - Extract 4 + Z-DEVD-FMK; $\mathbf{J}$ - Extract 5, K - Extract $5+$ Z-DEVD-FMK.

implicated in inflammation and carcinogenesis may be useful as cancer chemopreventive drugs.

On the other hand, data about the potential anticancer activity of extracts and phytochemicals of plants from the genus Helichrysum are scarce. The antiproliferative effect of the ethanol extract from Helichrysum maracandicum towards SENCAR mouse skin transformed cells has been demonstrated [20]. This extract suppressed the expression of p38 MAP kinase. An examination of the arzanol properties showed that this compound, which was isolated from Helichrysum italicum, did not exert cytotoxic action against monkey VERO cells at concentrations up to $40 \mu \mathrm{M}$ [24]. In contrast, another study showed that arzanol at a concentration of $50 \mu \mathrm{M}$ significantly suppressed the survival of human lung carcinoma A549 cells [18]. It should be mentioned that methanolic extracts prepared from different Helichrysum species were found to inhibit DNA topoisomerase I [19]. Moreover, the cytotoxicity of Helichrysum gymnocephalum essential oil towards human breast adenocarcinoma MCF-7 cells has been documented [17].

The results presented herein demonstrate the selective dose-dependent cytotoxic actions of the five extracts isolated from the endemic plant species Helichrysum zivojinii against target cancer cell lines and against healthy immunocompetent PBMC that have been stimulated to proliferate, while their cytotoxic actions were not as pronounced against unstimulated PBMC. The observed selectivity in the antitumor effects of the extracts against specific malignant cell types could be attributed to the actions of different Helichrysum zivojinii constituents on target molecules of the signal transduction pathways that regulate cell proliferation and apoptosis. Furthermore, each of the investigated extracts exhibited considerably stronger cytotoxicity to HeLa, Fem-x and K562 cells when compared to PBMC, both resting and PHA-stimulated, which points to the cancer specificity of their actions. It is noteworthy that when these extracts were applied at concentrations that were highly cytotoxic to malignant cells, they demonstrated very low toxicity towards healthy immunocompetent $\mathrm{PBMC}$, the key players in immune defenses against tumors. The good selectivity of their antitumor actions highlights the significant anticancer potential of Helichrysum zivojinii extracts. The prominent antitumor properties of these extracts need to be examined further in in vivo studies.

It should be stressed that all of these extracts exhibited weaker cytotoxic effects against unstimulated PBMC in comparison to stimulated $\mathrm{PBMC}$. This finding indicates that the extracts possess the ability to inhibit the proliferation of PHA-stimulated PBMC. Thus, these agents may even suppress certain immune functions, particularly non-specific antigen stimulation. Additionally, the observed lower activities against resting PBMC than against mitogen-stimulated PBMC point to components in pathways regulating cell proliferation as the possible molecular targets of the Helichrysum zivojinii extracts. However, it is very important to note that when extracts 1 , 2 and 3 were applied at lower concentrations, they stimulated the proliferation of resting PBMC. This growth stimulation effect of lower concentrations of extracts is in accordance with the well-known effect of very small doses of X rays on enhanced proliferation of irradiated cells [25]. The observed effects of low concentrations of these extracts on one of the main components of the immune response point to the possibility of their use to enhance immunity. It would be interesting to investigate their action towards different PBMC subpopulations and elucidate the potential mechanisms through which they stimulate proliferation. The possible immunostimulatory effects of extracts at lower concentrations might be explained by a modulation in lymphocyte cytokine production, including IL-2, IFN- $\gamma$, as well as IL-4 and IL-6. The immunoregulatory actions of phenolic compounds, such as quercetin, kaempferol and apigenin, have been reported [26-28]. Considering the presented results, the effects of the extracts on PBMC might be mediated through NF-kB.

Examination of in vitro cytotoxicity revealed that extracts 1 and 2 might be a significant source of novel promising anticancer compounds in view of their pronounced cytotoxic activities against HeLa, Fem-x and especially against K562 cells, as well as their high selectivity in the antitumor actions against cancer cells in comparison to healthy PBMC. Chemical analyses of the Helichrysum zivojinii extracts showed the presence of phenolic compounds whose antitumor potential has already been documented. The bioactive flavone apigenin that was found in extracts 2-5 has been reported to exhibit anticancer activities against different types of malignant cells including breast, cervical, ovarian, prostate, colon, gastric, liver and lung cancers, as well as skin and thyroid cancer, diverse hematological malignancies and neuroblastoma [28] and references cited therein]. The cytotoxic activities of extracts 2-5 may be at least in part due to the flavonoid naringenin. This flavonoid has been shown to exert 
cytotoxicity towards various malignant cell lines, such as breast cancer cell lines (MCF-7, MDA-MB-231), cervix adenocarcinoma (HeLa), liver cancer (HepG2, Hep3B, Huh7), pancreas cancer (PK-1), colon cancer (Caco-2), stomach cancer (KATOIII, MKN-7) and leukemia cells (Jurkat, HL-60, U937, NALM-6, THP-1) [29-31]. Additionally, the cancer-preventive and cancer-suppressive properties of quercetin, whose $\mathrm{O}$-glycosides were identified in extracts 3, 4 and 5, have been documented as well [32]. The antiproliferative and pro-apoptotic effects of quercetin were shown against the HeLa cell line [33].

Morphological analysis of the mode of HeLa cell death, together with the cell cycle analysis, showed that the treatment of HeLa cells with higher concentrations of the examined extracts induced apoptotic cell death. To confirm the pro-apoptotic action of the tested Helichrysum zivojinii extracts and to identify the caspases implicated in the employed apoptotic pathways, specific caspase inhibitors were used (Z-DEVD-FMK, Z-IETD-FMK, Z-LEHDFMK). A prominent decrease in the percentages of subG1 apoptotic HeLa cells after treatments with each of the tested extracts in combination with specific caspase inhibitors compared to the percentages of subG1 cells after treatments with only the corresponding extracts, indicates that each of the five extracts induced apoptosis through the activation of caspase-3, the main effector caspase, as well as through the activation of caspase- 8 and caspase- 9 . We conclude that the constituents of the Helichrysum zivojinii extracts triggered apoptosis in HeLa cells through the intrinsic pathway mediated by caspase- 9 , and the extrinsic pathway mediated by caspase-8. In addition, the crosstalk between these two apoptotic pathways should also be considered. Due to their ability to promote apoptotic cell death in cancer cells, the investigated extracts and their constituents may have significant anticancer potential. It is worth noting that antitumor drugs that induce apoptosis and thereby suppress the further growth of tumors play important roles in the clinical treatment of malignancies. In addition to the pronounced inhibition of proliferation and survival of target malignant cells, the lower cytotoxicity of Helichrysum zivojinii extracts against healthy PBMC is a promising lead for future studies.

\section{Conclusions}

Data from this in vitro study clearly demonstrate the prominent antitumor potential of five extracts prepared from the endemic plant species Helichrysum zivojinii, which can be attributed to their selective and pronounced antiproliferative and pro-apoptotic actions towards specific malignant cells in comparison to healthy PBMC. Prospective cancer-suppressive effects of the tested extracts should be further evaluated in in vivo experiments.
Competing interests

The authors declare that they have no competing interests.

\section{Authors' contributions}

IM performed all analyses of the anticancer properties of investigated extracts, interpreted obtained data and wrote the first and last version of the manuscript. IA participated in design of the study, prepared extracts, performed chemical characterization, interpreted data and wrote the part of the manuscript. $̌ Z Z$ participated in acquisition and analysis of data. MJ carried out chemical analyses of the extracts. W and SM participated in design of the study and interpreted obtained data. ZJ designed the research on anticancer properties of tested extracts, interpreted obtained data, participated in writing the manuscript and critically revised the manuscript. All authors have read and approved the final version of the manuscript.

\section{Acknowledgments}

The authors are grateful to the Ministry of Education, Science and Technological Development of the Republic of Serbia for the financial support (Projects 175011 and 172053). Also the authors would like to thank Tatjana Petrović for her excellent technical assistance. For the supply of plant material, we thank National park Galičica, Ohrid, Macedonia. We thank Andon Bojadži and Oliver Avramoski, National park Galičica.

\section{Author details}

${ }^{1}$ Institute of Oncology and Radiology of Serbia, Pasterova 14, 11000, Belgrade, Serbia. ${ }^{2}$ Institute for Chemistry, Technology and Metallurgy, University of Belgrade, Njegoševa 12, 11000, Belgrade, Serbia. ${ }^{3}$ Faculty of Chemistry, University of Belgrade, Studentski trg 16, 11000, Belgrade, Serbia.

Received: 13 September 2012 Accepted: 12 February 2013 Published: 18 February 2013

\section{References}

1. Amin ARMR, Kucuk O, Khuri FR, Shin DM: Perspectives for cancer prevention with natural compounds. J Clin Oncol 2009, 27:2712-2725.

2. Mehta RG, Murillo G, Naithani R, Peng X: Cancer chemoprevention by natural products: how far have we come? Pharm Res 2010, 27:950-961.

3. Neergheen VS, Bahorun T, Taylor EW, Jen LS, Aruoma Ol: Targeting specific cell signaling transduction pathways by dietary and medicinal phytochemicals in cancer chemoprevention. Toxicology 2010, 278:229-241.

4. Surh YJ: Cancer chemoprevention with dietary phytochemicals. Nat Rev Cancer 2003, 3:768-780.

5. Lourens ACU, Viljoen AM, van Heerden FR: South African Helichrysum species: a review of the traditional uses, biological activity and phytochemistry. J Ethnopharmacol 2008, 119:630-652.

6. Passalacqua NG, Guarrera PM, De Fine G: Contribution to the knowledge of the folk plant medicine in Calabria region (Southern Italy). Fitoterapia 2007, 78:52-68.

7. Redžić SS: The ecological aspect of ethnobotany and ethnopharmacology of population in Bosnia and Herzegovina. Coll Antropol 2007, 31:869-890.

8. Sezik E, Yesilada E, Honda G, Takaishi Y, Takeda Y, Tanaka T: Traditional medicine in Turkey X. Folk medicine in Central Anatolia. J Ethnopharmacol 2001, 75:95-115.

9. Aiyegoro OA, Okoh Al: Preliminary phytochemical screening and in vitro antioxidant activities of the aqueous extract of Helichrysum longifolium DC. BMC Complement Altern Med 2010, 10:21.

10. Angioni A, Barra A, Arlorio M, Coisson JD, Russo MT, Pirisi FM, Satta M, Cabras P: Chemical composition, plant genetic differences, and antifungal activity of the essential oil of Helichrysum italicum G. Don ssp. microphyllum (Willd) Nym. J Agric Food Chem 2003, 51:1030-1034.

11. Appendino G, Ottino M, Marquez N, Bianchi F, Giana A, Ballero M, Sterner O, Fiebich BL, Munoz E: Arzanol, an anti-inflammatory and anti-HIV-1 phloroglucinol a-pyrone from Helichrysum italicum ssp. microphyllum. J Nat Prod 2007, 70:608-612.

12. Aslan M, Deliorman Orhan D, Orhan N, Sezik E, Yesilada E: In vivo antidiabetic and antioxidant potential of Helichrysum plicatum ssp. plicatum capitulums in streptozotocin-induced-diabetic rats. J Ethnopharmacol 2007, 109:54-59. 
13. Meyer JJ, Afolayan AJ, Taylor MB, Engelbrecht L: Inhibition of herpes simplex virus type 1 by aqueous extracts from shoots of Helichrysum aureonitens (Asteraceae). J Ethnopharmacol 1996, 52:41-43.

14. Nostro A, Bisignano G, Cannatelli MA, Crisafi G, Germanò MP, Alonzo V: Effects of Helichrysum italicum extract on growth and enzymatic activity of Staphylococcus aureus. Int I Antimicrob Agents 2001, 17:517-520.

15. Sala A, Recio MC, Giner RM, Máñez S, Ríos JL: New acetophenone glucosides isolated from extracts of Helichrysum italicum with antiinflammatory activity. J Nat Prod 2001, 64:1360-1362.

16. Süzgeç S, Meriçli AH, Houghton PJ, Çubukçu B: Flavonoids of Helichrysum compactum and their antioxidant and antibacterial activity. Fitoterapia 2005, 76:269-272.

17. Afoulous S, Ferhout H, Raoelison EG, Valentin A, Moukarzel B, Couderc F, Bouajila J: Helichrysum gymnocephalum essential oil: chemical composition and cytotoxic, antimalarial and antioxidant activities, attribution of the activity origin by correlations. Molecules 2011, 16:8273-8291.

18. Bauer J, Koeberle A, Dehm F, Pollastro F, Appendino G, Northoff H, Rossi A Sautebin L, Werz O: Arzanol, a prenylated heterodimeric phloroglucinyl pyrone, inhibits eicosanoid biosynthesis and exhibits anti-inflammatory efficacy in vivo. Biochem Pharmacol 2011, 81:259-268.

19. Kucukoglu O, Ozturk B, Kamataki T, Topcu Z: Inhibitory activities of Helichrysum taxa on mammalian type I DNA topoisomerase. Pharm Biol 2006, 44:189-193.

20. Yagura T, Motomiya T, Ito M, Honda G, lida A, Kiuchi F, Tokuda H, Nishino H: Anticarcinogenic compounds in the Uzbek medicinal plant, Helichrysum maracandicum. J Nat Med 2008, 62:174-178,

21. Mosmann T: Rapid colorimetric assay for cellular growth and survival: application to proliferation and cytotoxicity assays. J Immunol Methods 1983, 65:55-63.

22. Ohno M, Abe T: Rapid colorimetric assay for the quantification of leukemia inhibitory factor (LIF) and interleukin-6 (IL-6). J Immunol Methods 1991, 145:199-203.

23. Nobilli S, Lippi D, Witort E, Donnini M, Bausi L, Mini E, Capaccioli S: Natural compounds for cancer treatment and prevention. Pharmacol Res 2009, 59:365-378

24. Rosa A, Deiana M, Atzeri A, Corona G, Incani A, Melis MP, Appendino G, Dessí MA: Evaluation of the antioxidant and cytotoxic activity of arzanol, a prenylated a-pyrone-phloroglucinol etherodimer from Helichrysum italicum subsp. microphyllum. Chem Biol Interact 2007, 165:117-126.

25. Wu B, Wei Y, Liu FQ, Zhang Q, Wang CB, Bai H: Biological effects of low dose $\mathrm{X}$-irradiation on human bone marrow mesenchymal stem cells. J Exp Hematol/Chinese Assoc Pathophysiol 2011, 19:1214-1217.

26. Nair MP, Kandaswami C, Mahajan S, Chadha KC, Chawda R, Nair H, Kumar N, Nair RE, Schwartz SA: The flavonoid, quercetin, differentially regulates Th-1 (IFNY) and Th-2 (IL-4) cytokine gene expression by normal peripheral blood mononuclear cells. Biochim Biophys Acta 2002, 1593:29-36.

27. Okamoto I, Iwaki K, Koya-Miyata S, Tanimoto T, Kohno K, Ikeda M, Kurimoto $\mathrm{M}$ : The flavonoid Kaempferol suppresses the graft-versus-host reaction by inhibiting type 1 cytokine production and CD8+ T cell engraftment. Clin Immunol 2002, 103:132-144.

28. Shukla S, Gupta S: Apigenin: a promising molecule for cancer prevention. Pharm Res 2010, 27:962-978.

29. Kanno S, Tomizawa A, Hiura T, Osanai Y, Shouji A, Ujibe M, Ohtake T, Kimura K, Ishikawa M: Inhibitory effects of naringenin on tumor growth in human cancer cell lines and sarcoma S-180-implanted mice. Biol Pharm Bull 2005, 28:527-530.

30. Kanno S, Tomizawa A, Ohtake T, Koiwai K, Ujibe M, Ishikawa M: Naringenininduced apoptosis via activation of NF-KB and necrosis involving the loss of ATP in human promyeloleukemia HL-60 cells. Toxicol Lett 2006, 166:131-139.

31. Park JH, Jin CY, Lee BK, Kim GY, Choi YH, Yeong YK: Naringenin induces apoptosis through downregulation of Akt and caspase- 3 activation in human leukemia THP-1 cells. Food Chem Toxicol 2008, 46:3684-3690.

32. Murakami A, Ashida $\mathrm{H}$, Terao J: Multitargeted cancer prevention by quercetin. Cancer Lett 2008, 269:315-325.

33. Vidya Priyadarsini R, Senthil Murugan R, Maitreyi S, Ramalingam K, Karunagaran $D$, Nagini S: The flavonoid quercetin induces cell cycle arrest and mitochondria-mediated apoptosis in human cervical cancer (HeLa) cells through p53 induction and NF-KB inhibition. Eur J Pharmacol 2010, 649:84-91.

doi:10.1186/1472-6882-13-36

Cite this article as: Matić et al:: In vitro antitumor actions of extracts from endemic plant Helichrysum zivojinii. BMC Complementary and Alternative Medicine 2013 13:36.

\section{Submit your next manuscript to BioMed Central and take full advantage of:}

- Convenient online submission

- Thorough peer review

- No space constraints or color figure charges

- Immediate publication on acceptance

- Inclusion in PubMed, CAS, Scopus and Google Scholar

- Research which is freely available for redistribution 